\title{
Quality Requirements and Conformity of Welded Products in the Manufacturing Chain in Welding Network
}

\author{
Jenni Toivanen, Paul Kah, Jukka Martikainen \\ Laboratory of Welding Technology, Lappeenranta University of Technology, Lappeenranta, Finland \\ Email address: \\ paul.kah@lut.fi (P. Kah),jenni.toivanen@lut.fi (J. Toivanen)
}

\section{To cite this article:}

Jenni Toivanen, Paul Kah, Jukka Martikainen. Quality Requirements and Conformity of Welded Products in the Manufacturing Chain in Welding Network. International Journal of Mechanical Engineering and Applications. Vol. 3, No. 6, 2015, pp. 109-119.

doi: $10.11648 /$ j.ijmea.20150306.12

\begin{abstract}
The objective of this study is to examine the manufacturing and conformity of welded products and the significance of co-operation of different functions to welding quality. This study focuses on costs arising from nonconformity from the manufacturing perspective. It briefly discusses unnecessary costs, claim costs and warranty costs in the production chain. It furthermore takes an overview of challenges in welding manufacturing in the engineering field with empirical research in the industry and shows that failures and defects are identifiable and known in companies but very rarely the root cause of imperfections is investigated. The requirements from manufacturing go unrecognized at the many levels of organisation. One of the main obstacles to improving welding functions is the lack of co-operation and knowledge of the demands on welding. This can cause continuous nonconformity in products and in welding manufacturing. The observations have been collected from welding networks in engineering workshops where GMAW welding is a commonly used process. The results provide a framework for future research to define the importance of actions of different functions to the quality and costs of manufacturing.
\end{abstract}

Keywords: Welding Manufacturing, Welding Network, Product Conformity, Welding Quality, ISO 3834, Welding Production

\section{Introduction}

The product life cycle starts with different requirements and needs that are followed in manufacturing over the course of development and design phases [1]. Manufacturing is linked with many other stages, like design, purchasing and quality, and what becomes emphasised in welding. The quality of a product can have many different dimensions, for example, with regard to performance, conformity, service [2] and design [3].

It is generally accepted that different standards and requirements coordinate the level of quality in manufacturing. However, if these demands are not understood and met in the many stages of the manufacturing chain, it can cause unnecessary costs. This study concentrates on explaining the effects of quality of conformity, quality of performance and quality of profitability on the manufacturing chain in the welding network. Quality of performance comprises the relationship between design engineering and manufacturing.
The study is based on empirical research in a project focused on the development of welding networks. The functional framework of the welding manufacturing network is presented and discussed from overall quality and demand aspects. The study takes an overview of the challenges of welding manufacturing. It briefly discusses the unnecessary costs, claim costs and warranty costs in the production chain. The paper reviews the linkages between design, purchasing, manufacturing and quality. The quality requirements of welding by different functions and standards are also discussed. The observations at the empirical part of the study are collected from welding networks in engineering workshops where GMAW welding is a commonly used process, and the range of defects and costs studied relate to the process. This review creates a framework for future research on the profitability of the welding network from the viewpoint of manufacturing.

\section{Relation of Functions in Welding}

Welding is a special manufacturing process [4] because it 
is difficult to be verified and because of the many factors that affect the welding. Welding is nevertheless the most common joining process in the metal industry [5] and has an influence on several important aspects, for example, product reliability and human safety [6]. Operations before actual welding are an important factor in the quality of a complete weld. The requirements of welding raise complexity when ensuring the quality demands set for welded products with many cooperative manufacturers in the welding network. The product requirements and quality of conformity define the demands of manufacturing which every party of the manufacturing process have to follow.

\subsection{Conformable Welding Network}

Companies are confronting challenges with design, manufacturing and distribution time in a highly competitive environment $[7,8,9]$. At the same time they have to improve production efficiency and ensure cost control [9]. Supply chain quality is in a significant position when expecting to achieve competitive advantage [10] and because manufacturers continuously call for improvements in supplier performance [11]. Furthermore, products are getting more complex and they have to meet customers' expectations [12]. In a welding network, the focal company of the network in the manufacture of the end product [13] is responsible for quality demands being fulfilled at every stage of the manufacturing chain.

The manufacturing failures of welded structures and products can be a result of defects in the welded joint [6] but also due to imperfections in other activities in manufacturing. It is important to define the right quality level and product specifications, and to ensure the requirements of all functions in a company that affect welding. Manufacturers rarely know the actual welding cost in their production [14]. Coordinating welding operations closely internally but also among cooperating companies in the network may decrease unnecessary defects and claims. Knowledge on requirements and possible defects has a notable effect on achieving quality. Failure to recognise weld discrepancies and nonconformity during manufacturing when fulfilling the requirements results in costly rework and lost productivity [15]. Manufacturers who understand welding economics and value added techniques are more successful in local and also global markets [14].

\subsection{Impact of Design Engineering on Welding Manufacturing}

Welding as a manufacturing process deeply depends on the decisions of design engineering. The design and development processes include many tools that are utilised to assess manufacturing and increase co-operation with other functions of manufacturing and have a positive impact on costs. The concurrent engineering (CC) approach shortens the time from design to delivery where many phases of the product process are running simultaneously [16]. A wider perspective on product manufacturing can be gained with product life cycle management (PLM) which is a strategic approach to manage and support the life cycle of a product from development to withdrawal. All the information of the life cycle is determined in digital solutions. It is also an integrated approach to control and monitor the phases of product development [8.].

Usable approaches to increasing manufacturability and noticing the demands of manufacturing are the design methods from the perspective of other functions [17]. The design for $\mathrm{X}$ (DfX) method can be used to improve product design and the design process, for instance, manufacturability and assemblability [17]. The most commonly used DfX perspective, design for manufacturing (DFM) focuses on manufacturability in product design in the chosen manufacturing chain [17], whereas design for assembly (DFA) focuses on assembly by minimising the assembly efforts of a product [16]. Weldibng assemblies are subject to properly fitting parts and understanding the demands of welding. Design for manufacturing and assembly (DFMA) comprises both DFM and DFA [18] and enables reducing manufacturing costs while developing the product or designing a new one [19]. Fig. 1 describes the DFMA process where both aspects, manufacturing and assembly, have to be observed in a welding network where welded parts and sub-assemblies have to fit regardless of the different welding workshops where they are manufactured.

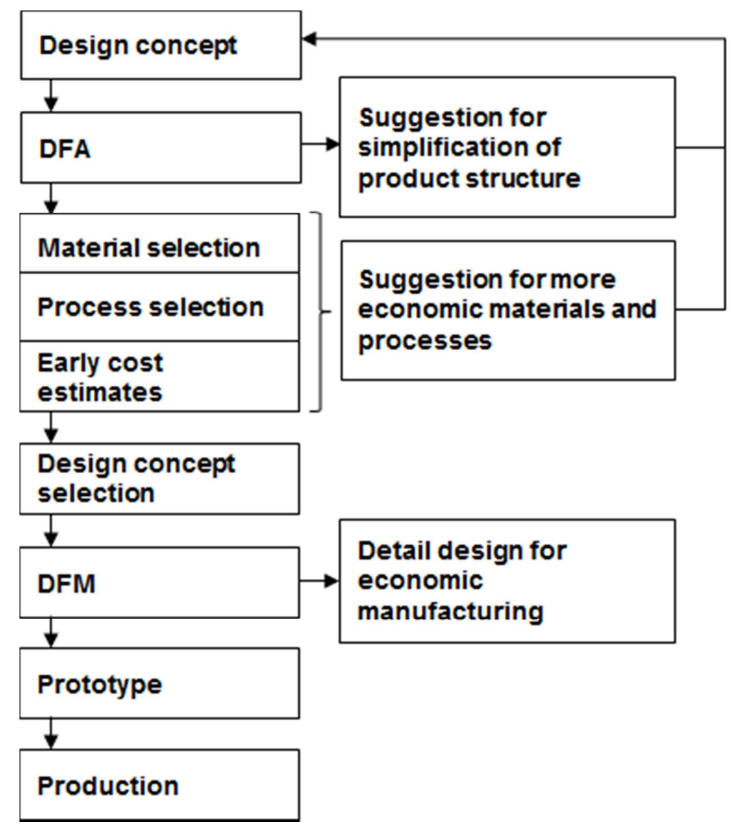

Figure 1. Simplified DFMA process in product design engineering [17] (Adapted).

\subsection{Welding Linkages}

Design engineering is not the only important function, but all departments of a company have their own specific subject field standards which define some issues of how things have to be done. Welding manufacturing includes four typical functions that have a remarkable influence on the success of producing products conforming to every 
demand assessed. If welding is one of the main manufacturing processes, all the other functions, like design engineering, manufacturing engineering, purchasing and quality control, also have a significant impact on welding. Therefore welding demands need to be understood in those functions of the company. Welding operations can be divided in three sections: before welding, during welding and after welding. The actual welding action can be mostly affected before welding, which is illustrated below in Fig. 2 on the important functions of welding.

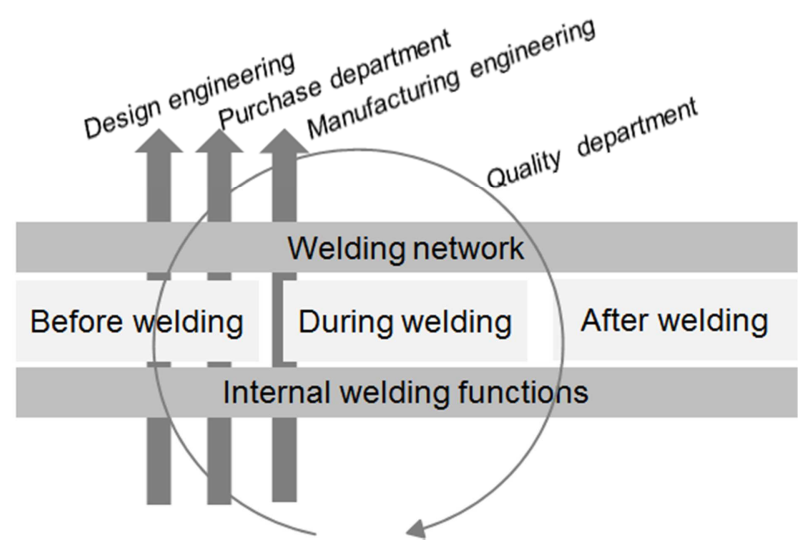

Figure 2. Important functions of welding in welding manufacturing.

The effectiveness of the linkage between design engineering and manufacturing mostly depends on the relations of people, employees' personal skills and capabilities, the willingness and ability to do intraorganisational co-operation, increasing knowledge and knowledge management practices and the commitment of the management to develop skills and co-operation [20]. Knowledge on welding is important in design and manufacturing [5]. Increasing knowledge and co-operation between the different functions is very important for the quality of manufacturing. Co-operative design tools, like DFM and DFMA, where manufacturing is considered at the early stage of the design process encourage co-operation with designers and manufacturing engineers and others affecting the costs of the end product at the early stages of design [17].

\section{Conformity of Welding}

Welding as a manufacturing process involves many different standards, guidelines and demands. Standards and technical reports are intended to help determine product specifications and quality requirements. The requirements do not, however, take into account all the demands of welded structures, the behaviour of material and the effects of the welding process. With great responsibility, design engineering and welding engineering require profound knowledge of process consequences. Product conformity assessment ensures the structure and quality requirements of the product. ISO 9000 defines the terms related to conformity: conformity, nonconformity, defect, preventive action, corrective action, correction, rework, regrade, repair, scrap, concession, deviation permit and release [4]. These terms can be divided related to welding actions possibly affecting before welding, actions which probably follow from welding and other actions after welding as shown in Fig. 3. The manufacturer of the end product defines the demands and quality requirements of the product. However, the end product can contain other conformities by standards or other third party requirements. These usually regard safety and environmental risks. Manufacturers can use valuable tools to prove the quality of a product. A sign of the good quality of welding manufacturing, controlled welding operations decrease production costs [21].

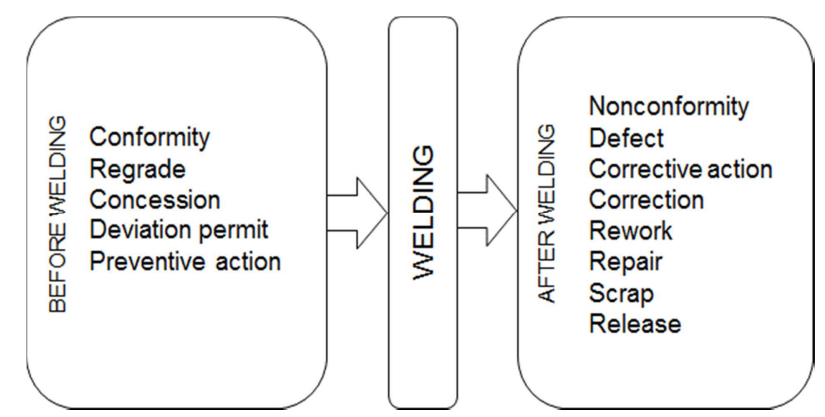

Figure 3. The terms of conformity in welding according to ISO 9000:2005.

\subsection{Welding Quality Requirements}

When a product involves complex requirements, composition or manufacturing processes, it can be defined as a complex product [22]. A welding assembly cannot be produced by choosing a fitting part for a sub-assembly or assembly, like the selective assembly technique which focuses on the fit between assembly components [22]. Therefore it is important to focus on the quality of each welded part.

Total product quality consists not only of the context of design, manufacture and post-sale service, but also of purchasing which are linked together [2]. The manufacturer, customer and third parties have many expectations with regard to the end product. Because welding processes have a significant influence on the quality of a product [23], the end result must meet all these expectations. The key to improving quality is to focus on the prevention of nonconformity [24]. Quality assurance verifies the conformity of a product and it has to reach the production process and cover the whole life cycle of a product [1]. Preventive actions can be, for example, design reviews, education, training, supplier selection, capability reviews and process improvement projects [24].

Quality can be understood in many different ways depending on the aspect. It is mostly related to product differentiation. Production quality can be understood by production efficiency [3], but it is also dependent on many functions around manufacturing. In welding production, it is important to consider the entire manufacturing process. Welding can be more effective with different tools, increased automation and fluent production. Regardless of the manufacturing technique, the product has to meet the 
requirements set. Control of faults and overall quality are the main things in welding design and manufacturing [25]. The quality demands of products, which are also related to the whole production efficiency, are examined in the following.

\subsection{Control of Welding Operations}

Table 1. ISO 3834 standard: Quality requirements for fusion welding of metallic materials.

\begin{tabular}{ll}
\hline $\begin{array}{l}\text { ISO 3834 Quality requirements for fusion welding of metallic } \\
\text { materials. }\end{array}$ \\
\hline ISO 3834-1:2005 & $\begin{array}{l}\text { Part 1: Criteria for the selection of the appropriate } \\
\text { level of quality requirements }\end{array}$ \\
ISO 3834-2:2005 & $\begin{array}{l}\text { Part 2: Comprehensive quality requirements. } \\
\text { ISO 3834-3:2005 }\end{array}$ \\
$\begin{array}{l}\text { Part Standard quality requirements. } \\
\text { Part 4: Elementary quality requirements. }\end{array}$ \\
$\begin{array}{l}\text { Part 5: Documents with which it is necessary to } \\
\text { conform to claim conformity to the quality } \\
\text { requirements of ISO 3834-2, ISO 3834-3 or ISO }\end{array}$ \\
& 3834-4. \\
\hline
\end{tabular}

The ISO 3834 standard provides the basis for quality of manufacturing. It guides welding manufacturing by standards, which help organise manufacturing. It is a guideline to good welding production and continuous improvement. The standard emphasises the importance of welding coordination and control of welding operations. Adopting ISO 3834 to the course of actions can prevent critical damages because of controlled manufacturing [6]. The standard has five parts: the first one helps to choose the appropriate level of quality requirements, the subsequent three parts define quality requirement levels and the final part is a list of documents necessary when using and conforming to the quality requirements of ISO $3834-2$, ISO $3834-3$ or ISO 3834-4 [23]. Table 1 presents the parts of the ISO 3834 standard.

"ISO 3834 therefore provides a method to demonstrate the capability of a manufacturer to produce products of the specified quality" [23]. ISO 3834 thus provides the basis for welding operations. It includes many standards that are important when a product is manufactured by welding. It does not take account of design engineering details but emphasises co-operation between design and manufacturing. There are also many other standards that affect actual welding. For example, design engineering has own requirements to assess the demands of a product structure, but also most of the welding decisions are made in design engineering. There are standards that define the general overview of welding and also have a direct effect on welding functions, the welding process and welding details, like ISO 5817 and ISO 13920 [26, 27], or define the details of manufacturing, for example, the welding process and welding consumables, like ISO 14341 and ISO 14175 [28, 29]. Table 2 presents examples of weld requirements according to the ISO 5817 standard. The examples illustrate the expected result of welding with limits depending on the quality grade.

Table 2. Limits for imperfections divided according to quality levels of ISO 5817 [26] (Adapted).

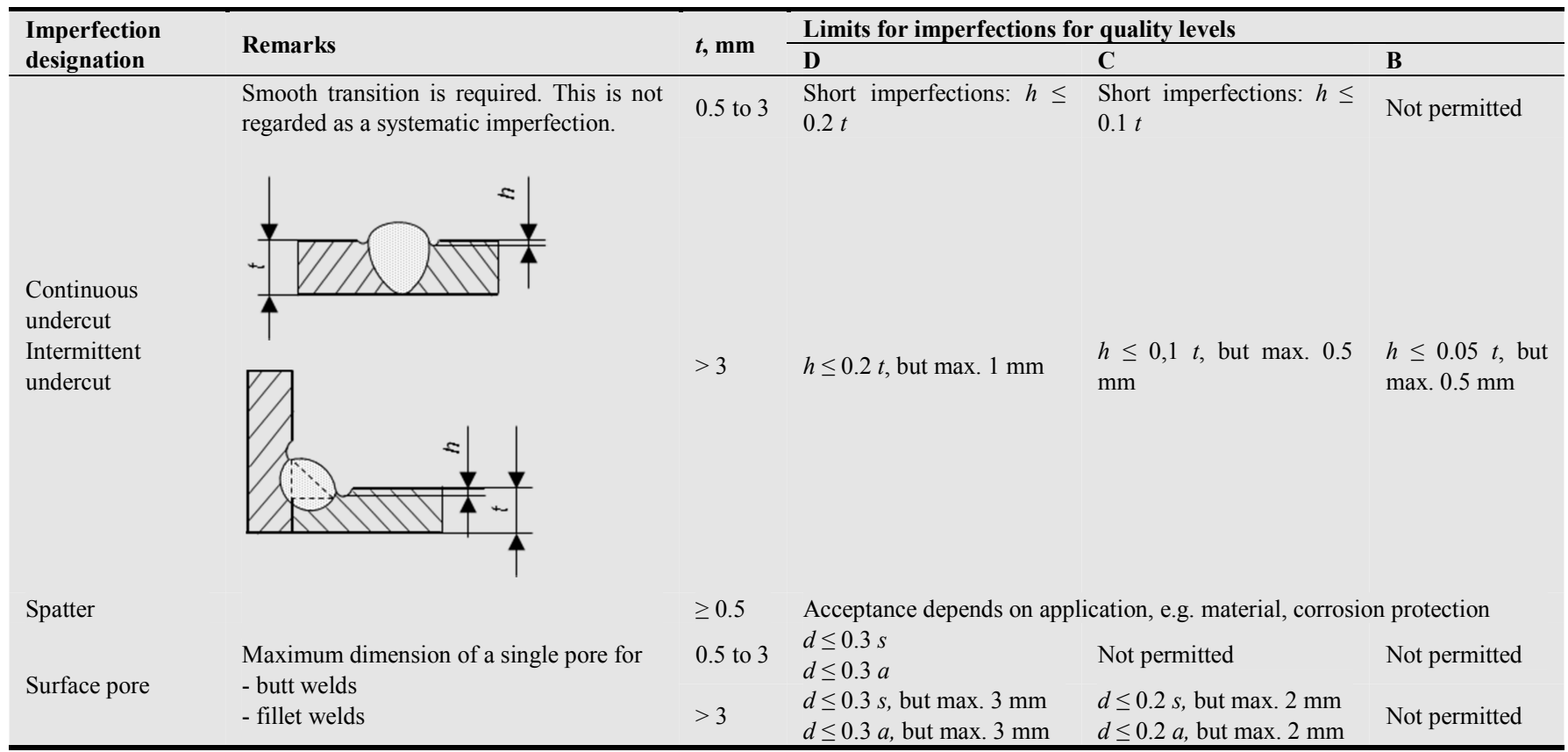

The link between design engineering and manufacturing is complex because different demands affect each other. Besides ISO 5817, there can be other demands that have an effect on weld quality, e.g. finish requirements. The ISO 8501-3 standard provides requirements for painting or related products. The requirements have to be noticed already in welding preparation and also during the welding process, such as finishing. The standard ISO 8501-3 includes preparation grades which describe the quality of product surface before painting. Preparation grades are P1 - Light preparation, P2 - 
Thorough preparation and P3 - Very thorough preparation. P1 allows an unfinished surface or only minimum preparation. P2 and P3 demand more remedial efforts [30]. Table 3 shows requirements for each preparation grade of the current standard.

Table 3. Imperfections and preparation grades according to ISO 8501-3 [30] (Adapted).

\begin{tabular}{|c|c|c|c|}
\hline Type of imperfection & P1 & P2 & P3 \\
\hline Welding spatter & $\begin{array}{l}\text { Surface shall be free of all loose } \\
\text { welding spatter [see a)] }\end{array}$ & $\begin{array}{l}\text { Surface shall be free of all loose } \\
\text { and lightly adhering welding } \\
\text { spatter [see a) and b)] Welding } \\
\text { spatter shown in c) may remain }\end{array}$ & $\begin{array}{l}\text { Surface shall be free of all welding } \\
\text { spatter }\end{array}$ \\
\hline & $\begin{array}{l}\text { Surface shall be } \\
\text { free from welding slag }\end{array}$ & $\begin{array}{l}\text { Surface shall be free from welding } \\
\text { slag }\end{array}$ & $\begin{array}{l}\text { Surface shall be free from welding } \\
\text { slag }\end{array}$ \\
\hline & No preparation & $\begin{array}{l}\text { Surface shall be free from sharp or } \\
\text { deep undercuts }\end{array}$ & $\begin{array}{l}\text { Surface shall be free from } \\
\text { undercuts }\end{array}$ \\
\hline $\mathrm{R}$ & No preparation & No preparation & $\begin{array}{l}\text { Edges shall be } \\
\text { rounded with a } \\
\text { radius of not less than } 2 \mathrm{~mm} \text { (see } \\
\text { ISO 12944-3) }\end{array}$ \\
\hline
\end{tabular}

Companies can also have other international or national standards in use and define their own requirements for products and manufacturing. Table 4 presents one national standard on the requirements for welding. It sets extra demands for companies when usually quality grade 05 is used [31]. This particular grade assures a good base for painting, and the requirements have to be applied in every section of manufacturing, including welding. If the main supplier adopts quality level $\mathrm{C}$ of welding imperfections and other specific demands, like SFS 8145 offers, the same demands apply to the welding network. These supplementary demands are not necessarily known throughout the company or the whole network. The requirements of different standards can cause confusion about the total requirements of quality in products and manufacturing.

Table 4. Quality grades for mechanical preparations [31].

\begin{tabular}{|c|c|c|c|c|c|c|c|c|}
\hline \multirow{2}{*}{ Object } & \multirow{2}{*}{ No. } & \multirow{2}{*}{ Action } & \multicolumn{6}{|c|}{ Quality grade of preparation } \\
\hline & & & 01 & 02 & 03 & 04 & 05 & 06 \\
\hline \multirow{12}{*}{$\begin{array}{l}\text { Weld } \\
\text { joints }\end{array}$} & 1 & Weld slag is to be & & & & & & \\
\hline & & removed & & & & & & \\
\hline & 2 & $\begin{array}{l}\text { Pieces of wire } \\
\text { electrode are to be }\end{array}$ & & & & & & \\
\hline & & removed & & & & & & \\
\hline & 3 & $\begin{array}{l}\text { Welding spatters that } \\
\text { can be loosened with }\end{array}$ & & & & & & \\
\hline & & $\begin{array}{l}\text { a scraper are to be } \\
\text { removed }\end{array}$ & & & & & & \\
\hline & 4 & Welding spatters are & & & & & & \\
\hline & 5 & $\begin{array}{l}\text { to be removed } \\
\text { Open pores are to be }\end{array}$ & & & & & & \\
\hline & & repaired & & & & & & \\
\hline & 6 & Undercuts are to be & & & & & & \\
\hline & & repaired & & & & & & \\
\hline & 7 & $\begin{array}{l}\text { Sharp peaks are to be } \\
\text { removed }\end{array}$ & & & & & & \\
\hline
\end{tabular}

Product quality requirements have to coincide with the parts designed so that they can be manufactured without rework or extra costs. The lack of knowledge on the manufacturing challenges can cause increasing manufacturing costs due to claims and warranty costs. Standards help to determine the requirements, but designers have to understand manufacturing to satisfy the level of quality and yet achieve profitability. Steel products, commonly used in welding structures, are an example of this. The tolerance rates of raw material can be a challenge to manufacturing and have a direct influence on functionality, costs and quality of manufacturing [32]. Narrow tolerances can cause high costs [33, 34] but also problems with succeeding welds without preparation, finishing or rework. On the other hand, too wide tolerances can cause variability in the products $[33,34]$. The focal company can have its own level of tolerances depending on the part, but the requirements that affect the tolerance need to be understood in manufacturing engineering or by the welding coordinator to achieve appropriate and competitive production.

The EN 10219-2 and EN 10210-2 standards define requirements for hollow section steel products [35, 36]. Corresponding international standards are ISO 10799-2 and ISO 12633-2 [37, 38]. Some common causes of unnecessary fixing or rework in welding are the concavity $x 1$, convexity $\mathrm{x} 2$ (Fig. 4a), twist v (Fig. 4b) and straightness e (Fig. 4c) of these kinds of products. Standards enable imperfections in dimensions. This jeopardises compatibility when parts are meant to be fitted into each other, demonstrated in Fig. 5, or in other tightly dimensioned joining. 


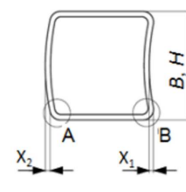

a

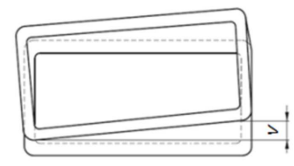

b

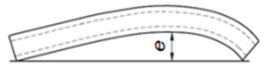

Figure 4. Concavity (a), convexity (b), twist and straightness (c) in hollow section steel products [35, 36] (Adapted).

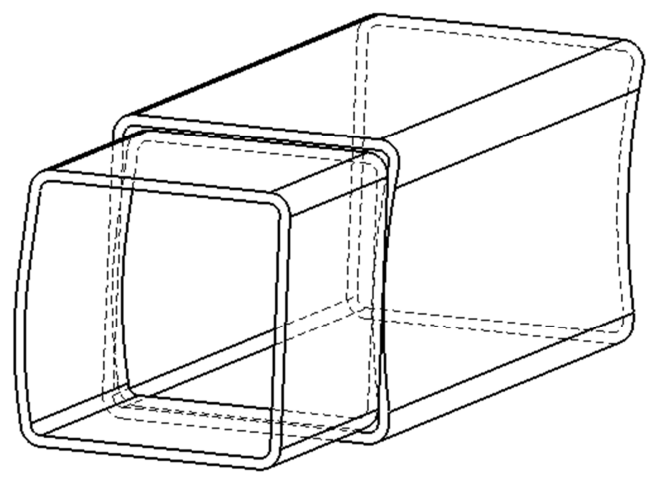

Figure 5. An example of compatibility risked due to dimensional imperfections enabled by standards for a square tube.

Empirical research shows that the requirements focused on products and manufacturing are insufficiently recognised at the many levels of a company. This causes deficiency of knowledge on the quality and manufacturing demands. This is one reason of nonconformity in manufacturing. Departments of design engineering and purchasing are inadequately aware of the extent of welding quality standards. The consequences of welding and preventive actions are also unknown at the management level. The management understands the importance of quality and pressures to decrease defects, but the foundation of possible welding development remains unrecognised. The control of the quality department is usually not focused on following the defect rate of welding operations in-house, but on the conformity of deliveries from collaboration partners and suppliers.

Welding is a challenging manufacturing method, and not all the challenges can be solved when applying standards and other regulations. The purpose of use of the end product can present even more requirements, for example, with regard to quality and strength, which have to be taken into account in design engineering. Also, the requirements of welding need to be understood. The welder's professional skills are primarily notable after appropriate requirements for welding. Defects can occur in actual welding which can be prevented with suitable pre-actions and the sufficient knowledge and training of welders [21, 39]. Welding coordination is in a significant role to stimulate co-operation among the departments of the company and distribute welding knowledge in every requisite stage as a response to control over quality and manufacturing demands in the welding network.

\section{Costs of Conformity}

Usually quality costs focus on an individual company and internal costs instead of the whole production chain [40]. In a welding network, quality costs are more closely followed by the focal company. Quite often internal quality costs are understood to include daily work rather than own countable costs. From a wider perspective, costs can be divided into different departments or other functional areas with responsibility for own departmental costs [41]. It has been known for a long time that quality costs are measurable; they can be planned, analysed and prevented and are higher when failures are detected at the end of production or by the customer [42]. Still, the focal company rarely uses this information effectively in every day work in a network. Empirical research proves that failures and defects are identifiable and known in companies, but actions to find the root of the problem are fewer, which creates continuous costs.

\subsection{Quality Costs}

The manufacturing process generates costs, also related to quality. Costs of quality result from not producing requisite quality or ensuring quality in accordance with requirements. Quality costs have more strategic and economic importance than earlier costs [40] by affecting profit and helping to identify the weak points in the process [43]. Many models have been developed to measure or identify quality costs. The most basic scheme is to find prevention, appraisal and failures of the process and costs.

The traditional model of developing the quality level of a company is the prevention-appraisal-failure (PAF) model [44]. It is a commonly used method for measuring quality costs [24], and it is the basic scheme in many reconstitutions of quality cost count models. Fig. 6 illustrates the PAF model. The model focuses on finding the quality level that is suitable for a company determined by specifications and the total quality costs which increase concurrently with the quality level [44]. Quality level q of a product can be defined considering a number of non-defective items, and defect rate $\mathrm{d}$ defective items. When increasing the quality level, it is profitable to invest in prevention and appraisal functions [44]. When total quality costs rise over the optimal quality level q, quality costs $\mathrm{C}(\mathrm{q})$ contradict with the profitability of product manufacture. Many authors divide quality costs in two parts where quality costs $\mathrm{C}(\mathrm{q})$ are a summary of prevention cost $\mathrm{C}(\mathrm{p})$ and appraisal cost $\mathrm{C}(\mathrm{a})$ : C_ $\left(q=C \_p+C \_a\right)$, and the total quality costs $T C(q)$ are a summary of $\mathrm{C}(\mathrm{q})$ and failure costs $\mathrm{N}(\mathrm{q})$ : [TC】 _ $\left(\mathrm{q}=\mathrm{C} \_\mathrm{q}+\mathrm{N} \_\mathrm{q}\right)$ [24]. Another way to divide quality costs is to regroup the total quality costs into costs of conformance (prevention and appraisal costs) and costs of nonconformance (costs of internal failure and costs of external failure) [43].

The PAF model is based on the notion that higher quality causes higher costs. This view does not support the idea of continuous improvement and decreasing quality costs with 
higher quality. However, it has been shown that it depends on the effectiveness of the company's quality improvement program whether the quality costs are increasing or decreasing when producing higher quality and a more effective quality improvement program decreases quality costs and produces higher quality [44]. Poor design quality can also create higher production costs [3], and too narrow tolerances can generate unnecessary production costs, even though the variability of the product decreases, the quality of manufacturing improves and quality losses are reduced [34]. The balance between the requirements and manufacturing quality has to be observed.

Continuous improvement is important when the company wants to improve product quality and the flow of production. Fig. 7 describes the quality cost rates of prevention, appraisal and failure costs in continuous improvement. It has been noticed that the failure cost and total quality cost rates never reach zero because of the uneconomical aspect and because the rate turns upward at some point [42]. Figures 6 and 7 are not completely accurate for welding where qualitativeness cost more than increased quality, when quality assurance is at a sensible level with all design and manufacture demands. To maintain competitive advantage, continuous improvement of product quality is essential [1]. The main supplier has to ensure this improvement in the network.

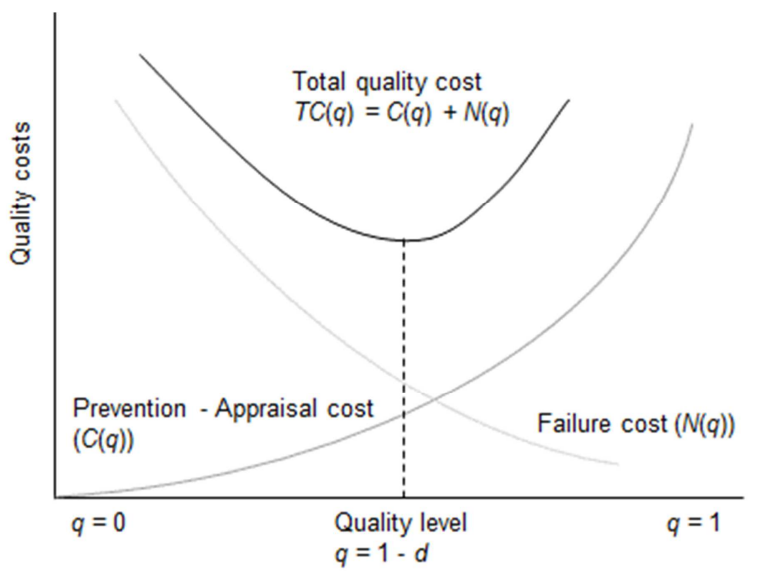

Figure 6. PAF model for quality costs [44] (Adapted).

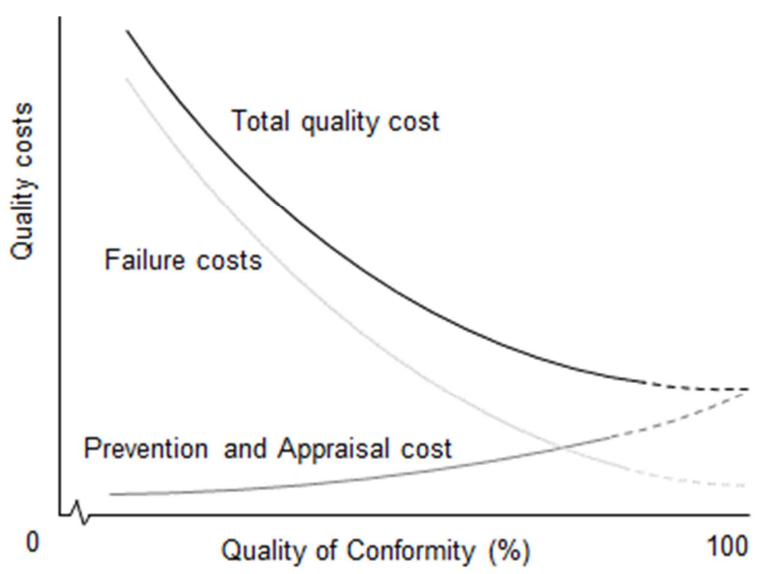

Figure 7. Quality cost behaviour according to continuous improvement [42] (Adapted).
Failure costs can be divided into internal and external failure costs. Internal failure costs result from a product that does not conform to the requirements before it meets the customer, whereas external failure costs occur if the product is already shipped to the customer with defects [40]. Table 5 shows examples of reasons for quality costs divided into categories prevention, appraisal, internal failure and external failure costs.

Table 5. Example reasons for quality costs divided by different categories [44] (Adapted).

\begin{tabular}{|c|c|c|c|}
\hline $\begin{array}{l}\text { Prevention } \\
\text { costs } \\
\end{array}$ & $\begin{array}{l}\text { Appraisal } \\
\text { costs }\end{array}$ & $\begin{array}{l}\text { Internal failure } \\
\text { costs }\end{array}$ & $\begin{array}{l}\text { External } \\
\text { failure costs }\end{array}$ \\
\hline $\begin{array}{l}\text { Process control } \\
\text { Product and } \\
\text { service design } \\
\text { and redesign } \\
\text { Process design } \\
\text { Supplier } \\
\text { relations, audit } \\
\text { and screening } \\
\text { Preventive } \\
\text { maintenance } \\
\text { Training and } \\
\text { quality circles }\end{array}$ & $\begin{array}{l}\text { Raw material } \\
\text { inspection } \\
\text { In-process } \\
\text { inspection } \\
\text { Final } \\
\text { inspection } \\
\text { Inspection } \\
\text { material and } \\
\text { services } \\
\text { Quality audit }\end{array}$ & $\begin{array}{l}\text { Scrap } \\
\text { Rework } \\
\text { Equipment } \\
\text { repair } \\
\text { Process } \\
\text { downtime } \\
\text { Re-inspection of } \\
\text { products }\end{array}$ & $\begin{array}{l}\text { Warranty } \\
\text { charges } \\
\text { Litigation and } \\
\text { liability } \\
\text { Complaint } \\
\text { handling } \\
\text { Returns } \\
\text { Rework on } \\
\text { returns } \\
\text { Lost sales } \\
\text { Penalties and } \\
\text { allowances }\end{array}$ \\
\hline
\end{tabular}

Table 6. Actions affecting welding quality before welding, during welding and after welding.

\begin{tabular}{|c|c|c|c|}
\hline & \multicolumn{3}{|c|}{ ACTIONS AFFECTING QUALITY } \\
\hline & Before welding & $\begin{array}{l}\text { During } \\
\text { welding }\end{array}$ & $\begin{array}{l}\text { After } \\
\text { welding }\end{array}$ \\
\hline APPRAISAL & $\begin{array}{l}\text { Specifications } \\
\text { Quality requirements } \\
\text { Manufacturing } \\
\text { processes } \\
\text { Training } \\
\text { Welding knowledge } \\
\text { Welding network } \\
\text { control } \\
\text { Material procurement } \\
\text { Manufacturing details } \\
\text { Workshop control } \\
\text { Quality input } \\
\text { Co-operation } \\
\text { Design \& Development }\end{array}$ & $\begin{array}{l}\text { Visual } \\
\text { inspection } \\
\text { Welders } \\
\text { professional } \\
\text { skills } \\
\text { Equipment } \\
\text { performance } \\
\text { Welding area } \\
\text { control } \\
\text { Specifications } \\
\text { follow }\end{array}$ & $\begin{array}{l}\text { Visual } \\
\text { inspection } \\
\text { Other quality } \\
\text { inspections }\end{array}$ \\
\hline CORRECTIVE & Quality processing & $\begin{array}{l}\text { Scrap } \\
\text { Rework }\end{array}$ & $\begin{array}{l}\text { Unnecessary } \\
\text { inspections } \\
\text { Grinding } \\
\text { Fine-tuning } \\
\text { Finishing } \\
\text { Scrap } \\
\text { Rework }\end{array}$ \\
\hline
\end{tabular}

Besides considering the cost of quality, quality costs can also be assessed to manage losses. There are a lot of hidden costs that come from manufacturing loss and design loss. They are identified when quality actions are unsuccessful and generate costs. [45.] The welding manufacturing process involves unnecessary quality costs when products do not meet the requirements set on conformity. Table 6 shows actions affecting quality divided into categories before welding, during welding and after welding. The preventive actions of quality assurance create costs, but 
they have to be integrated into every day work and related to the level of quality and requirements. Relating quality and profitability is the most effective way to prevent failures [24]. It is also important to invest in productivity and quality knowledge to get efficient benefits to produce cost reductions and quality increase [46]. Training is one of the most important things to increase knowledge and skills in welding. Increasing welding knowledge and training is remarkably important in developing welding production and decreasing costs [21].

\subsection{Influence of Nonconformity}

Related to production costs, the most important decisions regarding costs and quality demands are usually made during the design stage [47]. The design phase includes the specifications of the weld structure, like the component shapes, positions of joints and also joining methods, but the whole welding network, including suppliers' own collaboration partners, has an effect on product costs by their actions in production.

Decisions made during design and manufacturing have an influence on reliability [48] and can prevent unnecessary costs caused by nonconformity. Waste can be defined in several ways. Waste losses can be related to time, motion and process flow and come from waiting, non-value added time, inappropriate layout and poor communication [49]. The waste costs of welding result from the process not working properly. Co-operation among the management, design engineering, manufacturing engineering, welding coordination, welding manufacturing and quality assurance is in an important role in profitable welding manufacturing (Fig. 8). Welding coordination links the functions together with responsibility for welding operations [13]. Each function has a specified role to achieve high quality and a profitable result.

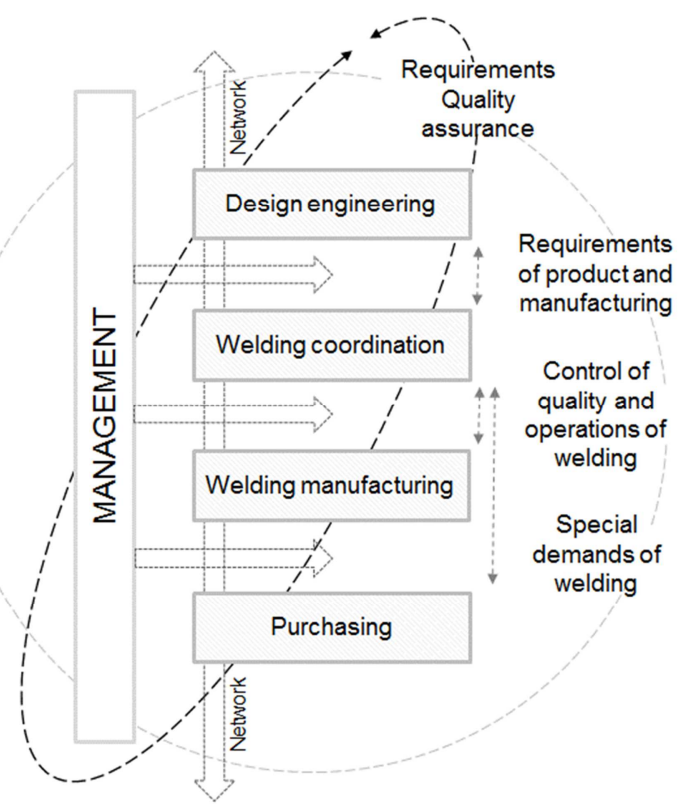

Figure 8. Links among the different functions of a company [13].
Costs arising from defects, faults, complaints and warranties are unprofitable items to a company. Cost of defects are gathered from different processes [49], and from the focal company's viewpoint, nonconformity costs from faults and defects arise not only from internal welding manufacturing, but also from the network. They are usually handled as complaints if defects are noticed by the focal company. Nonconformity is more costly than proper preventive actions in quality assurance. The work costs are only part of the total costs resulting from complaints and remanufacturing. Indirect costs come, for instance, from notice of defective processing, manufacturing engineering, welding engineering and other actions that follow from rework.

Often the closer the product is to the customer in the manufacturing chain, the greater the effect on corrective actions. Fig. 9 mirrors the cost effect from prevention to subsequent actions. The arrows present increasing quality costs during manufacturing with defects, faults, complaints and warranties. Warranties are signed between the manufacturer and the client and they oblige the manufacturer to answer for the product's operation during the warranty period $[50,51]$, and recovery actions create costs. It is not unambiguous how warranty costs occur, e.g. from warranty service and warranty maintenance, whereas defects, faults and complaints are connected to the manufacturing process and arise from the focal company to the network.

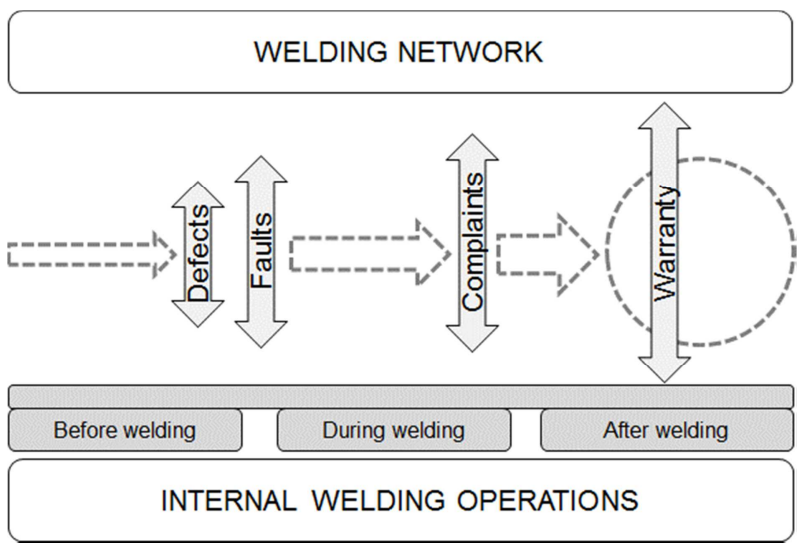

Figure 9. Cost effects from preventive to subsequent actions in welding manufacturing.

\section{Conclusion}

Welding is the most common joining process in the metal industry, and the customer has many demands on the end product to which the main supplier has to respond. Confronted with the challenges of a competitive environment, companies are improving their production efficiency and reducing production costs. When more than one producer is involved with a product, the whole production chain has to meet the requirements. The focal company has the responsibility to fulfil the requirements for every part of the whole final product. This also includes quality costs which come from ensuring the quality requirements. The welding process affects the costs of 
manufacturing and profitability; the costs have to be in control at every stage from the product's design to the manufacturing process and quality assurance. When a company manufactures products using welding in their main manufacturing process or some critical components by welding, it is important that all functions around welding are controlled. This denotes co-operation among different functions, like design engineering, purchasing, manufacturing engineering and the quality department. It is a deceptive presumption that the demands of welding need to be mastered only in the welding workshop.

Coordinating welding functions gives an advantage for profitable and quality manufacturing. For example, the ISO 3834 standard ensures welding quality requirements and gives guidelines to good welding production. It emphasises continuous improvement, controlling of welding operations and the importance of a welding coordinator. By using standards, the tool of whole production to improve welding operations, the benefits are wider than the mere focus on welding action. It is important that the company itself can answer the different quality requirements with the standards or use the standards to determine its own quality level and guidelines clarifying production to increase productivity and profitability.

Empirical research on a welding network shows that failures and defects are identifiable and known but actions to find their root cause are few. The requirements focused on product or welding manufacturing are unrecognised at the many levels of organisation, which can cause continuous nonconformity in products. One of the main obstacles to improving welding functions is the lack of co-operation and knowledge of demands on welding. This shows as deficiency in reviews on the requirements of design engineering, the purchasing department and welding coordinators and uncertainty over manufacturing demands fulfilling the quality requirements of products. Furthermore, the lack of welding knowledge among welders causes defects and also disinclination to consider the relationship of various functions affecting welding. Observing only the complaint and quality costs of network co-operation companies does not give the right idea of all the nonconformity costs of production. By increasing welding knowledge and training and clarifying the requirements of product and manufacturing among all the parties of the manufacturing chain, the demands become distinct and easier to control.

Further work will be needed to analyse the detection of defects to find the root cause of defects, faults, claims and complaints. The impact of costs of quality and complaints at the network level and the effect on the end product is an interesting area for study to further enlighten the impact of nonconformity on manufacturing.

\section{References}

[1] X. Tang and H. Yun, Data model for quality in product lifecycle, Computers in industry, 59 (2-3), 2008, pp. 167-179. doi: 10.1016/j.compind. 2007. 06. 011.
[2] D.N.P. Murthy and K.R. Kumar, Total product quality, International Journal of Production Economics, vol. 67 (3), 2000, pp. 253-267. doi: 10.1016/S0925-5273(00)00026-8.

[3] J. Freiesleben, J, Proposing a new approach to discussing economic effects of design quality, International Journal of Production Economics, vol. 124 (2), 2010, pp. 348-359. doi: 10.1016/j.ijpe.2009.11.030.

[4] ISO 9000:2005. Quality management systems. Fundamentals and vocabulary, International Organization for Standardization.

[5] P. Kah and J. Martikainen, Current trends in welding processes and materials: improve in effectiveness, Reviews on Advanced Materials Science, vol. 30, 2012, pp. 189-200.

[6] D.N. Shackleton, Reducing failure risk in welded components, Welding in the World, vol. 50 (9-10), 2006, pp. 92-97. doi: 10.1007/BF03263449.

[7] J. Váncza, L. Monostori, D. Lutters, S.R. Kumara, M. Tseng, P. Valckenaers and H. Van Brussel, Cooperative and responsive manufacturing enterprises, CIRP Annals Manufacturing Technology, vol. 60 (2), 2011, pp. 797-820. doi: 10.1016/j.cirp.2011.05.009.

[8] V. Nosenzo, S. Tornincasa, E. Bonisoli and M. Brino, Open questions on Product lifecycle Management (PLM) with $\mathrm{CAD} / \mathrm{CAE}$ integration, International Journal on Interactive Design and Manufacturing, vol. 8, 2014, pp. 91-107. doi: 10.1007/s12008-013-0184-1.

[9] F. Pan and R. Nagi, Multi-echelon supply chain network design in agile manufacturing, Omega, vol. 41 (6), 2013, pp. 969-983. doi: 10.1016/j.omega.2012.12.004.

[10] G. Xie, W. Yue, S. Wang and K.K. Lai, Quality investment and price decision in a risk-averse supply chain, European Journal of Operational Research, vol. 214 (2), 2011, pp. 403410. doi: 10.1016/j.ejor.2011.04.036.

[11] W. Wang, R.D. Plante and J. Tang, Minimum cost allocation of quality improvement targets under supplier process disruption, European Journal of Operational Research, vol. 228 (2), 2013, pp. 388-396. doi: 10.1016/j.ejor.2013.01.048.

[12] R. Jiang and D.N.P. Murthy, Impact of quality variations on product reliability, Reliability Engineering and System Safety, vol. 94 (2), 2009, pp. 490-496. doi: 10.1016/j.ress.2008.05.009.

[13] J. Toivanen, J. Martikainen and P. Heilmann, From supply chain to welding network: A framework of the prospects of networks in welding, Mechanika, vol. 21 (2), 2015, pp. 154160. doi: 10.5755/j01.mech.21.2.8463.

[14] D.K. Miller, Cost of Welding, Welding Design and Fabrication, vol. 3, 2004, pp. 32-37.

[15] W.C. LaPlante, How to Assure Quality in Outsourced Welded Products, Welding Journal, vol. 90 (10), 2011, pp. 42-46.

[16] F. Giudice, F. Ballisteri and G. Risitano, A Concurrent Design Method Based on DFMA-FEA Integrated Approach, Concurrent Engineering, vol. 17 (3), 2009, pp. 183-202. doi: $10.1177 / 1063293$ X09343337.

[17] T. Tomiyama, P. Gu, Y. Jin, D. Lutters, C. Kind and F. Kimura, Design methodologies: Industrial and educational applications, CIRP Annals - Manufacturing Technology, vol. 58, 2009, pp. 543-565. doi: 10.1016/j.cirp.2009.09.003. 
[18] D. Dewhurst, Design First, Lean Second, Assembly, 2011, pp. $62-68$.

[19] D. Hegland, DFMA Cuts Downstream Costs, Assembly, vol. $51(6), 2008,43-49$.

[20] R. Dekkers, C.M. Chang and J. Kreutzfeldt, The interface between "product design and engineering" and manufacturing: A review of the literature and empirical evidence, International Journal of Production Economics, vol. 144 (1), 2013, pp. 316-333. doi: 10.1016/j.ijpe.2013.02.020.

[21] J.R. Barckhoff, Total Welding Management, American Welding Society, 2010, pp. 1-6, 15-36.

[22] L. Liu, F. Zhu, J. Chen, Y. Ma and Y. Tu, A quality control method for complex product selective assembly processes, International Journal of Production Research, vol. 51 (18), 2013, pp. 5437-5449. doi: 10.1080/00207543.2013.776187.

[23] ISO 3834:2005. Quality requirements for fusion welding of metallic materials - Part 1-5, International Organization for Standardization.

[24] A. Kazaz, M.T. Birgonul and S. Ulubeyli, Cost-based analysis of quality in developing countries: a case study of building projects, Building and Environment, vol. 40 (10), 2005, pp. 1356-1365. doi: 10.1016/j.buildenv.2004.11.010.

[25] G. Casalino, S.J. Hu and W. Hou, Deformation prediction and quality evaluation of the gas metal arc welding butt weld, Proceedings of the Institution of Mechanical Engineers, vol. 217 (11), 2003, pp. 1615-1622. doi: $10.1243 / 095440503771909999$.

[26] ISO 5817:2014. Welding - Fusion-welded joints in steel, nickel, titanium and their alloys (beam welding excluded) Quality levels for imperfections, International Organization for Standardization.

[27] ISO 13920:1996. Welding - General tolerances for welded constructions. Dimensions for lengths and angles. Shape and position, International Organization for Standardization.

[28] ISO 14341:2010. Welding consumables - Wire electrodes and weld deposits for gas shielded metal arc welding of non alloy and fine grain steels. Classification, International Organization for Standardization.

[29] ISO 14175:2008. Welding consumables - Gases and gas mixtures for fusion welding and allied processes, International Organization for Standardization.

[30] ISO 8501-3:2006. Preparation of steel substrates before application of paints and related products - Visual assessment of surface cleanliness. Part 3: Preparation grades of welds, edges and other areas with surface imperfections, International Organization for Standardization.

[31] SFS 8145:2001. Anticorrosive painting. Quality grades of mechanical surface preparations for blast cleaned or blastcleaned and prefabrication primed steel substrates, Finnish Standards Association SFS.

[32] B. Li, X. Yang, Y. Hu and D. Zhang, Quality design of tolerance allocation for sheet metal assembly with resistance spot weld, International Journal of Production Research, vol. 47 (6), 2009, pp. 1695-1711. doi: $10.1080 / 00207540701644193$.
[33] M-Y. Liao, Economic tolerance design for folded normal data, International Journal of Production Research, vol. 48 (14), 2010, pp. 4123-4137. doi: 10.1080/00207540902960307.

[34] N.V.R. Naidu, Mathematic model for quality cost optimization, Robotics and Computer-Integrated Manufacturing, vol. 24 (6), 2008, pp. 811-815. doi: 10.1016/j.rcim. 2008. 03. 018.

[35] EN 10210-2:2006. Hot finished structural hollow sections of non-alloy and fine grain steels - Part 2: Tolerances, dimensions and sectional properties, European Committee for Standardization.

[36] EN 10219-2:2006. Cold formed welded structural hollow sections of non-alloy and fine grain steels - Part 2: Tolerances, dimensions and sectional properties, European Committee for Standardization.

[37] ISO 10799-2:2011. Cold-formed welded structural hollow sections of non-alloy and fine grain steels - Part 2: Dimensions and sectional properties, International Organization for Standardization.

[38] ISO 12633-2:2011 Hot-finished structural hollow sections of non-alloy and fine grain steels - Part 2: Dimensions and sectional properties, International Organization for Standardization.

[39] D.C. Li, Research on Quality Management of manufacturing Equipment Welding Technology, Applied Mechanics and Materials, vol. 192, 2012, pp. 415-419. doi: 10.4028/www.scientific.net/AMM.192.415.

[40] K.K. Castillo-Villar, N.R. Smith and J.L. Simonton, A model for supply chain design considering the cost of quality, Applied Mathematical Modelling, vol. 36 (12), 2012, pp. 5920-5935. doi: 10.1016/j.apm.2012.01.046.

[41] A.I. Pettersson and A. Segerstedt, Measuring supply chain cost, International Journal of Production Economics, vol. 143 (2), 2012, pp. 357-363. doi: 10.1016/j.ijpe.2012.03.012.

[42] D.H. Besterfield, Quality control, Prentice-Hall, Inc, 1994, pp. 405-406, 420-421.

[43] O. Staiculescu, A new vision of cost: an essential optimization tool for managerial accounting, Procedia - Social and Behavioral Sciences, vol. 62, 2012, pp. 1276-1280, May 2012 [World Conference on Business, Economics and Management (BEM-2012), Antalya, Turkey]. doi: 10.1016/j.sbspro. 2012. 09. 218.

[44] S. Kim and B. Nakhai, The dynamics of quality costs in continuous improvement, International Journal of Quality \& Reliability Management, vol. 25 (8), 2008, 842-859. doi: $10.1108 / 02656710810898649$.

[45] G. Giakatis, T. Enkawa and K. Washitani, Hidden quality costs and the distinction between quality cost and quality loss, Total Quality Management, vol. 12 (2), 2001, pp. 179-190. doi: $10.1080 / 09544120120011406$.

[46] J. Vörös, The dynamics of price, quality and productivity improvement decisions, European Journal of Operational research, vol. 170 (3), 2006, pp. 809-823. doi: 10.1016/j.ejor.2004.08.001.

[47] P.G. Maropoulos, Z. Yao, H.D. Bradley and K.Y.G. Paramor, An integrated design and planning environment for welding Part 1. Product modeling, Journal of Materials Processing Technology, vol. 107 (1-3), 2000, pp. 3-8. doi: 10.1016/S0924-0136(00)00708-1. 
[48] D.N.P. Murthy and I. Djamaludin, I, New product warranty: A literature review, International Journal of Production Economics, vol. 79 (3), 2002, pp. 231-260. doi: 10.1016/S0925-5273(02)00153-6.

[49] C. Hicks, O. Heidrich, T. McGovern and T. Donnelly, A functional model of supply chains and waste, International Journal of Production Economics, vol. 89 (2), 2004, pp. 165174. doi: 10.1016/S0925-5273(03)00045-8.
[50] M. Shafiee and S. Chukova, Maintenance models in warranty: A literature review, European Journal of Operational Research, vol. 229 (3), 2013, pp. 561-572. doi: 10.1016/j.ejor.2013.01.017.

[51] M.R. Karim and K. Suzuki. Analysis of warranty claim data: a literature review, International Journal of Quality \& Reliability Management, vol. 22 (7), 2005, pp. 667-686. doi: $10.1108 / 02656710510610820$. 